\section{Analysis of the Swampland Bearing Capacity for the Construction of Non Engineered Structures in Earthquake Prone Areas}

\author{
Muhammad Fauzi ${ }^{1) *}$, Dwi Setyawan ${ }^{2)}$, \\ Budhi Setiawan $^{3)}$, Ridhah Taqwa ${ }^{4}$
}

\begin{abstract}
1) Civil Engineering, Bengkulu University. Kampus Jalan Kandang Limun Bengkulu. He is currently undertaking studied at his PhD program at Environmental Science, Sriwijaya University
\end{abstract}

2) Soil Science and Environment Science, Sriwijaya University. Jalan Padang Selasa 524, Bukit Besar, Palembang 30139, Indonesia

3) Civil Engineering and Environment Science, Sriwijaya University

4) Social Science and Environment Science, Sriwijaya University

Received: January3o, 2014/ Accepted: September3o, 2014

\section{Abstract}

The population of Bengkulu city - an area highly prone to earthquakes - are currently unable to adapt their built environment appropriately. Construction of houses has been undertaken with insufficient knowledge of standards to secure the dwelling against the danger of earthquakes. Due to the rapid population growth in the city of Bengkulu, housing construction has been undertaken in a swamp area. Limited land for residential development has forced people to build houses on wetlands, in an area that is not appropriate for such construction. This study aimed to identify the characteristics and bearing capacity of swamp-land for public housing. The method used in this study was a field investigation, specifically in the form of land investigation undertaken using hand drill tools or sondir appliances. The characteristics of the land in Muara Bangkahulu and Sungai Serut Districts were identified using hand bore tools, which indicated very soft clays. The medium-soft clays and clay had bearing capacities ranging from $0.20287 \mathrm{~kg} / \mathrm{cm}^{2}$ to $2.10771 \mathrm{~kg} / \mathrm{cm}^{2}$. The land characteristics of the Ratu Agung District were identified using sondir tools, indicating soil types: sandy silt and silt, sand, and silty sand with a bearing capacity ranging from $0.80824 \mathrm{~kg} / \mathrm{cm}^{2}$ to $2.52576 \mathrm{~kg} / \mathrm{cm}^{2}$.

Keywords: Non-Engineered Structures; Land; swamps; Bearing Capacity.

\section{INTRODUCTION}

Indonesia is a region with huge potential for the occurrence of earthquakes, so technicians need to pay serious attention to ensure that construction is resistant to earthquakes. The rise of buildings being constructed in areas that have a low bearing capacity, will lead to new vulnerabilities. This case study considers Bengkulu province, which is geologically located at the confluence of several active tectonic plates, having implications for the possibility of natural disasters, this leads to buildings becoming prone to earthquakes.

Residential buildings that have suffered a lot of damage when earthquakes hit are community-owned buildings, as opposed to government-owned buildings that have under gone expert building design based on sound calculations. In the building houses, the population has not adapted to the environment of Bengkulu city which is very prone to earthquakes. Constructors of houses were not equipped with enough knowledge about the correct way to build a good home which is secure against the danger of earthquakes. Construction of housing is undertaken in areas that are not appropriate for settlement and housing. One of the reasons that people build in these areas is that their is limited land for settlement, forcing people to build on swampland.

At the same time as the population is unable to adapt to the environment of Bengkulu city which is very prone to earthquakes, construction of houses has not incorporated knowledge of the best methods to build a good home which is secure against the danger of earthquakes. In fact, due to the rapid population growth in the city of Bengkulu, the people were constructing houses in swamp areas. Limited land for residential development forces people to build on wet lands, and swamp is land which is not appropriate to be used for housing. This is due to fact that marsh areas have a low bearing capacity.

The studies conducted to date have been focused on building safer houses resistant to earthquakes on dry land. House construction in wetlands (swamps) has not been considered to date. Attempts have been made to educate the general public and even to elementary school students over the years in the form of socializing, training, workshops, Training of Trainers (TOT) and similar activities, however the fact that the city Bengkulu is in an earthquake-prone area has led to the loss of valuable structures.

Corresponding Author Tel.: 081367690429;

E-mail: fauzi70_ros@yahoo.com 


\section{BASIC THEORY}

\subsection{Natural disasters.}

The definition of a disaster according to Constitution no. 24 Year 2007 in Hardoyo, et al, is an event that threatens the lives and livelihoods, resulting both from natural and nonnatural factors and human factors, causing loss of life, environmental damage, loss of property, and the psychological impact to the society (2011).

According to Constitution No. 27 Year 2007 in Hardoyo, et al, a disaster is an event that is caused by natural causes or human actions, which resulted in the changes in physical properties and or biodiversity of an area; and resulted the loss of life, property, or damage in the area(2011).

According to Agus, earthquakes are characterized by physical symptoms of the earth pulsating at different intensities (2002). When the ground (earth), voltage exceeds the elastic limit a split (rupture) occurs, and a relative sliding motion occurs between opposite sides and produces what is called a geological fault. A sudden energy release that is then transferred through the ground in the form of vibrations of elastic waves emitted in all directions from the point of collapse. This wave displacement at a location on Earth is referred to as an earthquake.

\subsection{Community Strategy Adaptation in Disaster}

Hardesty, in Hardoyo, et al, 2011 elaborated on adaptations, suggesting that: "Adaptation is the process of room mates beneficial relationships which are established and maintained between an organism and its environment"(1977). The intent of this statement is that the adaptation is the process of the establishment and maintenance of good relations which are mutually beneficial between organisms and their environment.

Meanwhile, according to the cultural ecologists (Alland, 1975; Harris, 1968; Moran, 1982) in Hardoyo, et al, 2011, a definition is provided suggesting that adaptation is an adjustment method used by humans in their lives to respond to changes in the environment and social space.

\subsection{Over-function of Land}

The need for land conversion occurs due to two things: firstly because of the necessity to meet the needs of residents who are increasing in number and secondly, relating to the increasing demand for a better quality of life. Factors affecting the conversion can be divided into two categories, namely:

1. Factors at the macro level

These factors include the growth of industry, the growth of settlements, population growth, and government intervention and economic marginalization.
2. Factors at the micro level

These factors include the pattern of household income (the economic structure of the household), household wealth (household economic value orientation), and the survival strategies of households (household economic behaviour).

\subsection{Swamp land}

According to the Ministry of Settlement and Regional Infrastructure (2006), the marsh is one potential natural resource spread across the Indonesian archipelago. Most of the wetlands are on the islands of Sumatra, Kalimantan, and Irian Jaya. Along with the increasing need for food and good land for settlement and for industry, the development of marsh has been carried out.

Swamp land is an area of land which has the topography of a relatively flat or slightly concave land and can be naturally waterlogged throughout the year or during a specified period of sufficient length. A wetlands designation is made for all inundated areas, which suffer inundation which is seasonal or permanent and are overgrown by vegetation.

\subsection{House Building}

A house basically consists of the house foundation, body and roof of the building. The structural components consist of:

\section{The top structure (Upper Structure)}

Structure (upper structure) that is part of the building that is located on the top floor surfaces such as walls, columns, doors, windows, ring beams and roof trusses and their parts (Supribadi, 2002). These structures must be able to guarantee the upper structure in terms of safety and comfort. Therefore, the materials used in this building have a design criteria, which includes but is not limited to, being strong, fire resistant, durable for long term use, easy to obtain and set up, as well as being economical and easy to maintain.

2. The under structure (Sub-Structure)

The Bottom structure ( sub- structure) are the parts of the building which are located on the bottom floor of a building or the part that is in the soil, such as concrete blocks (sloop) and foundation (Supribadi, 2002). The building below is intended to hold the entire weight of the building on the foundation including its own weight and the weight of the soil directly above the foundation.

\subsection{Soil Investigation}

Sub surfaces oil investigation is important before building any structure. Failure to recognize this requirement may result in the need to make a costly relocation plan or spending extra money for alternative 
accommodation. Support is provided primarily from the ground under the building, and is absolutely necessary. Although, to some, it may seem unimportant and is often taken for granted it can be a primary cause of building failure (Dunn, Anderson, Kiefer, 1992).

There are many methods of soil investigation in the field, such as the drilling of test holes, wells and tunnels, mashed drilling, mechanical auger, drilling and washing, rotary drilling, drilling potable, hand drilling and so on (Reinhold, 1991).

\subsection{Bearing Capacity of Shallow Foundations}

Bearing capacity is the ability of the soil to support the load of the building situated on the foundation above. Bearing capacity of the soil acts as a soil shearing resistance against the decline that occurs as the result of loading, where the soil gives shearing resistance in each sliding plane area ( Hardiyatmo, 2002 in Rifandi, 2013).

\subsubsection{Bearing Capacity Through Hand bore Investigation Tool}

Allowable bearing capacity which can be provided by the foundation soil to the proportional foundation with a width of $\mathrm{B}$ is given in the following equation, known as the Terzaghi bearing capacity formula (Das, 1994 in Ariani, 2013).

$$
\begin{aligned}
& q_{u l t}=c N_{c}+\gamma D_{f} N_{q}+\frac{1}{2} \gamma B N_{\gamma}(1) \\
& \gamma=\frac{W}{V}
\end{aligned}
$$

where :

$$
\begin{aligned}
& \text { qult }=\text { ultimate bearing capacity at the } \\
& \text { elongated foundation }\left(\mathrm{kg} / \mathrm{cm}^{2}\right) \\
& \text { c = soil cohesion } \\
& \mathrm{D}_{f} \quad=\text { Depth of foundation }(\mathrm{cm}) \\
& \mathrm{N}_{\mathrm{c}}, \mathrm{N}_{\mathrm{q}}, \mathrm{N}_{\mathrm{Y}} \quad=\text { Terzaghi bearing capacity factor that }
\end{aligned}
$$
depends on the value of the soil friction angle $(\phi)$ ( Table 1.)

$$
\begin{aligned}
& \gamma \quad=\text { density of the soil }\left(\mathrm{kg} / \mathrm{cm}^{3}\right) \\
& \mathrm{W} \quad=\text { weight of soil }(\mathrm{kg}) \\
& \mathrm{V} \quad \quad=\text { Volume of soil }\left(\mathrm{cm}^{3}\right)
\end{aligned}
$$

Table 1Bearing capacity coefficient of Terzaghi

\begin{tabular}{ccccccc}
\hline \multirow{2}{*}{$\begin{array}{c}\text { Friction } \\
\text { angle }(\boldsymbol{\Phi})\end{array}$} & \multicolumn{5}{c}{ Terzaghi bearing capacity factor } \\
\cline { 2 - 7 } & $\mathbf{N}_{\mathrm{c}}$ & $\mathbf{N}_{\mathrm{q}}$ & $\mathbf{N}_{\mathrm{\gamma}}$ & $\mathbf{N}_{\mathrm{c}}{ }^{\prime}$ & $\mathbf{N}_{\mathrm{q}}{ }^{\prime}$ & $\mathbf{N}_{\mathrm{\gamma}}{ }^{\prime}$ \\
\hline $0^{\circ}$ & 5,71 & 1,00 & $\mathrm{O}$ & 3,81 & 1,00 & $\mathrm{o}$ \\
$5^{\circ}$ & 7,32 & 1,64 & $\mathrm{O}$ & 4,48 & 1,39 & $\mathrm{O}$ \\
$10^{\circ}$ & 9,64 & 2,7 & 1,2 & 5,34 & 1,94 & $\mathrm{o}$ \\
$15^{\circ}$ & 12,8 & 4,44 & 2,4 & 6,46 & 2,73 & 1,2 \\
$20^{\circ}$ & 17,7 & 7,43 & 4,6 & 7,90 & 3,88 & 2,0 \\
$25^{\circ}$ & 25,1 & 12,7 & 9,2 & 9,86 & 5,60 & 3,3 \\
$30^{\circ}$ & 37,2 & 22,5 & 20,0 & 12,7 & 8,32 & 5,4 \\
$35^{\circ}$ & 57,8 & 41,4 & 44,0 & 16,8 & 12,8 & 9,6 \\
$40^{\circ}$ & 95,6 & 81,2 & 114,0 & 23,2 & 20,5 & 19,1 \\
$45^{\circ}$ & 172 & 173 & 320 & 35,1 & 35,1 & 27,0 \\
\hline$S O u r c e$ &
\end{tabular}

Source: Nakazawa (2005) in Ariani (2013)
Table 2The Relation between Angle Slide to the Soil Type

\begin{tabular}{lc}
\hline \multicolumn{1}{c}{ Soil Type } & Friction Angle $(\phi)$ \\
\hline Sand Gravel & $35^{\circ}-40^{\circ}$ \\
Pebble gravel & $35^{\circ}-40^{\circ}$ \\
Dense Sand & $35^{\circ}-40^{\circ}$ \\
Sand Off & $30^{\circ}$ \\
Silty Clay & $25^{\circ}-30^{\circ}$ \\
Clay & $20^{\circ}-25^{\circ}$ \\
\hline
\end{tabular}

Source: Das (1994)

Advanced Groundwater Effect :

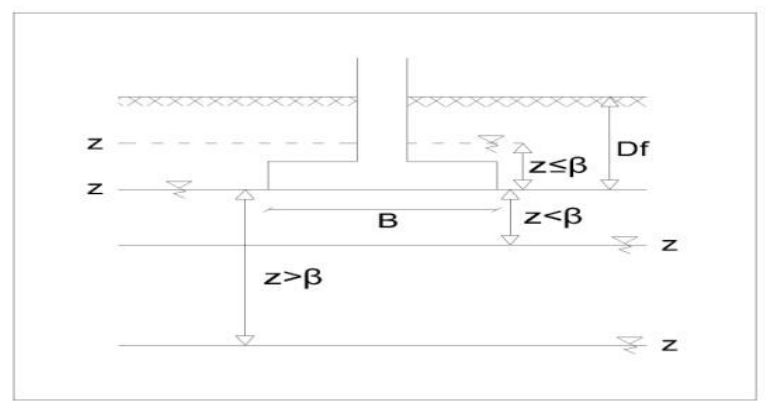

Figure 1 Advance Groundwater Conditions

Notes:

1) If the water level is above or equal to the foundation , the weight of the volume used in the $3^{\text {rd }}$ equation term must be effective volume weight or buoyancy volume weight $\left(\gamma^{\prime}\right)$, due to these conditions the shear zone located below the foundation fully sub merged under water, the value of the $2^{\text {nd }}$ rate equation for $\gamma D_{f}$, becomes:

$\gamma^{\prime}\left(\mathrm{D}_{\mathrm{f}}-\mathrm{d}_{\mathrm{w}}\right) \mathrm{d}_{\mathrm{w}}+\gamma_{\mathrm{b}}$

with $\gamma^{\prime}=\gamma_{\text {sat }}-\gamma_{w}$ and $d_{w}=$ depth of water table.

2) If the water level in the surface or $d w=0$, then the rate of $\gamma$ in the $2^{\text {nd }}$ equation term is replaced by $\gamma^{\prime}$, the same thing goes to the rate of $\gamma$ in the $3^{\text {rd }}$ equation term which uses the buoyant volume weight $\left(\gamma^{\prime}\right)$.

3) If the water level is deeper than the foundation wide or $\mathrm{z}>\beta$, $\mathrm{z}$ is the distance of groundwater level below the foundation base. The value of $\gamma-2$ of bearing capacity equation used is $\gamma_{b}$ or $\gamma_{d}$, as well as in a 3 rd equation term used value of wet weight volume $\left(\gamma_{t}\right)$ or dry $\left(\gamma_{d}\right)$. For this condition, the shear strength parameters used in the calculation is the shear strength parameters in effective tension reviews ( $c^{\prime}$ and $\left.\phi^{\prime}\right)$.

4) If the groundwater level is located at $z$ area below the foundation base $(z<\beta)$, the value of $\gamma$ in the $2^{\text {nd }}$ equation is replaced by $\gamma b$ or $\gamma d$, because the mass of soil in the shear zone is partially submerged in water, the weight of the soil that is applied in the $3^{\text {rd }}$ bearing capacity equation can be approximated by:

$$
\begin{aligned}
& \gamma_{\mathrm{rt}}=\gamma^{\prime}+(\mathrm{z} / \mathrm{B})\left(\gamma_{\mathrm{rt}}-\gamma^{\prime}\right)_{(4)} \\
& \gamma_{\mathrm{rt}}=\gamma_{\text {average }}(5)
\end{aligned}
$$


Table 3 The Relationship between Cohesion Values and Soil Type

\begin{tabular}{lc}
\hline \multicolumn{1}{c}{ Soil Type } & Cohesion $(c)\left(\mathrm{kg} / \mathrm{cm}^{2}\right)$ \\
\hline Rock & 100 \\
Silt & 0,75 \\
Clay & $0,1-0,2$ \\
Very soft clay & $0-0,48$ \\
Soft clay & $0,48-0,96$ \\
Stiff clay & $0,96-1,92$ \\
Stiff clay & $1,92-3,84$ \\
Very stiff clay & $3,84-7,66$ \\
Hard Clay & $>7,66$ \\
\hline
\end{tabular}

Source: Stanford University

\subsubsection{Bearing Capacity Tool Through investigation Sondir}

For foundations on sand layer, Meyerhof (1956) in Hardiyatmo (2002) suggested a simple equation to determine the bearing capacity of the ground clearance from the result of the Sondir test which is based on 1" degradation. Here is the allowable bearing capacity equation of rectangle foundation or elongated foundation where B has a width of 1.20 meters.

$$
q_{a}=\frac{q_{c}}{30}(5)
$$

Where :

$$
\begin{array}{ll}
\mathrm{q}_{\mathrm{a}} & =\text { Land Capability Centre }\left(\mathrm{kg} / \mathrm{cm}^{2}\right) \\
\mathrm{q}_{\mathrm{c}} & =\text { Pressure } / \text { Barriers Konus }\left(\mathrm{kg} / \mathrm{cm}^{2}\right)
\end{array}
$$

According to Nakazawa (2005) in Ariani (2013) in designing a safe structure of a satisfactory bearing capacity limit, the concept of allowable bearing capacity is acceptable. The concept of allowable bearing capacity is obtained by dividing the bearing capacity with the safety factor price.

$$
\begin{aligned}
& q_{\text {all }}=\frac{q_{u l t}}{F_{s}}(6) \\
& \text { Where: } \mathrm{q}_{\text {all }}=\text { allowable bearing capacity }\left(\mathrm{kg} / \mathrm{m}^{2}\right) \\
& \mathrm{q}_{\text {ult }}=\text { ultimate bearing capacity }\left(\mathrm{kg} / \mathrm{m}^{2}\right) \\
& \text { Fs = factor of safety ( safety factor ) is taken by } 3
\end{aligned}
$$

By using the graph in Figure 2, researchers were able to determine the type of soil for each layer

\section{RESEARCH METHOD}

The research was conducted by means of surveys, including interviews and field observations in order to obtain data. Data collection was conducted within a population of construction workers or owners of permanent houses within Bengkulu city. Samples were taken in three districts, namely Muara Bangkahulu District, Sungai Serut District and Ratu Agung District.

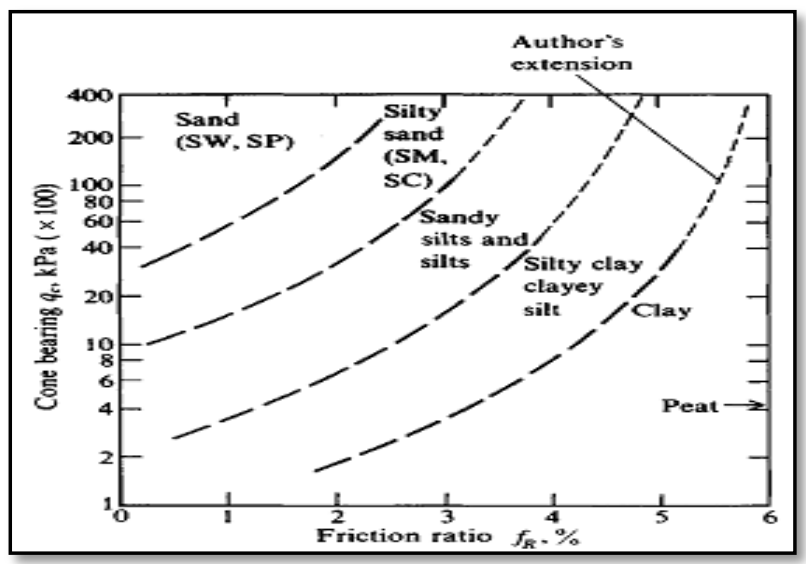

Figure 2 Graphs of Soil Properties with CPT

\subsection{The Primary Data}

The primary data obtained by interacting directly with the objects through observation, interview sand the distribution of questionnaires (regarding the technical and social aspects) directly to respondents at the research site. The soil investigation data used a handbore instrument in the Muara Bangkahulu District and Sungai Serut District and used a sondir instrument at the Ratu Agung District.

\subsection{Secondary Data}

The study of literature from several books related to building materials and home building structures in terms of the concept of earthquake resistant houses and collecting additional data from multiple agencies, including JICA data, Bappeda Bengkulu Province and Regional Disaster Management Agency (BPBD), PU, BPS, and completed from other sources, such as literature studies, information from the internet, and related facts relevant to this research were investigated to obtain secondary data.

\section{RESULT AND DISCUSSION}

\subsection{Wetland}

The data pertaining to the number of houses located in wetlands was obtained by observing wetland areas in the Google Earth application and observing field conditions. The large number of houses located in wetlands can be seen in Table 4 .

Table 4 Total Houses Located in Wetlands in Bengkulu City

\begin{tabular}{lccc}
\hline \multirow{2}{*}{ District } & \multicolumn{3}{c}{ Total Houses } \\
\cline { 2 - 4 } & $\mathbf{2 0 0 2}$ & $\mathbf{2 0 0 9}$ & $\mathbf{2 0 1 2}$ \\
\hline Sungai Serut & 2786 & 3674 & 4350 \\
Ratu Agung & 2721 & 2991 & 3277 \\
Muara Bangkahulu & 2966 & 3826 & 4037 \\
\hline
\end{tabular}

Source:Outcomes Research, 2013 
From Figure 3, Figure 4 and Figure 5 it is clear that the number of houses in wetlands from 2002 to 2012 has increased every year. The increasing needs of the community for the building of houses forces people to choose wetlands as a place to build their houses. The land that was originally wetlands or swampland becomes a land that had adapted to become land fill. Thus making wetlands or swamp areas increasingly narrower from year to year.

Here is the number of houses located in wetlands in the three observed districts:
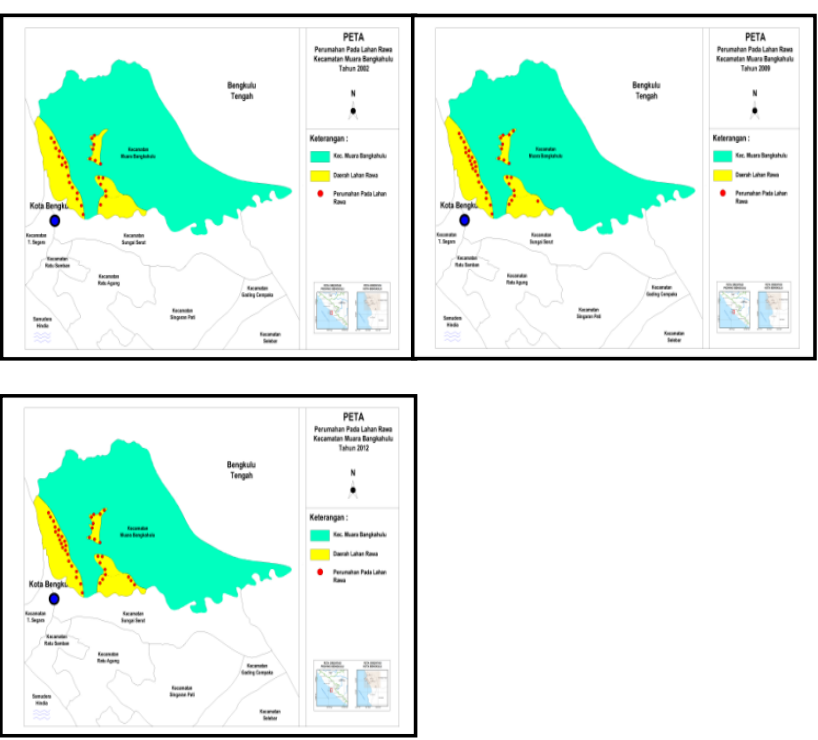

Figure 3 Total Houses

In Wetlands in Muara Bangkahulu District 2002, 2009 and 2012

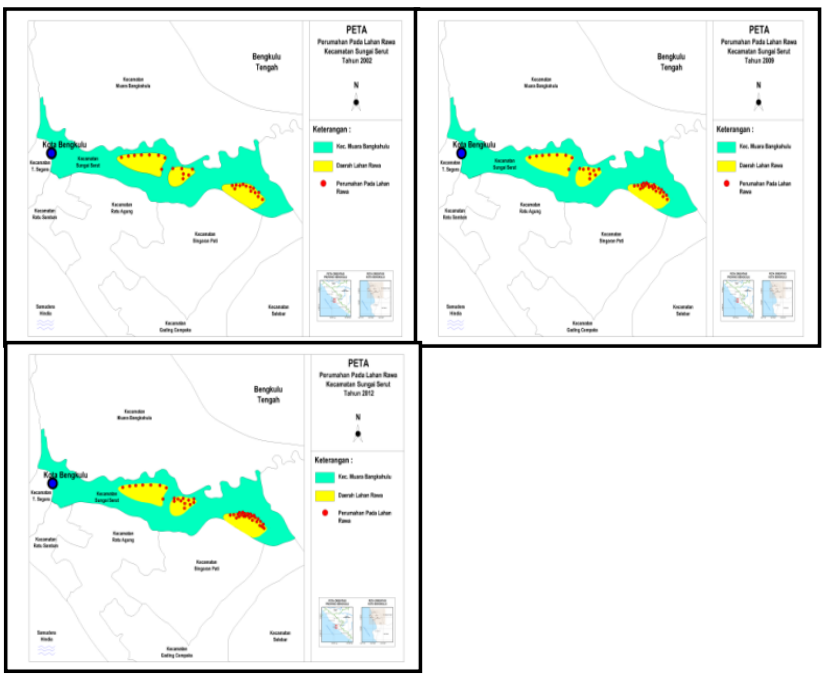

Figure 4Total Houses in Wetlands in Sungai Serut District 2002, 2009 and 2012

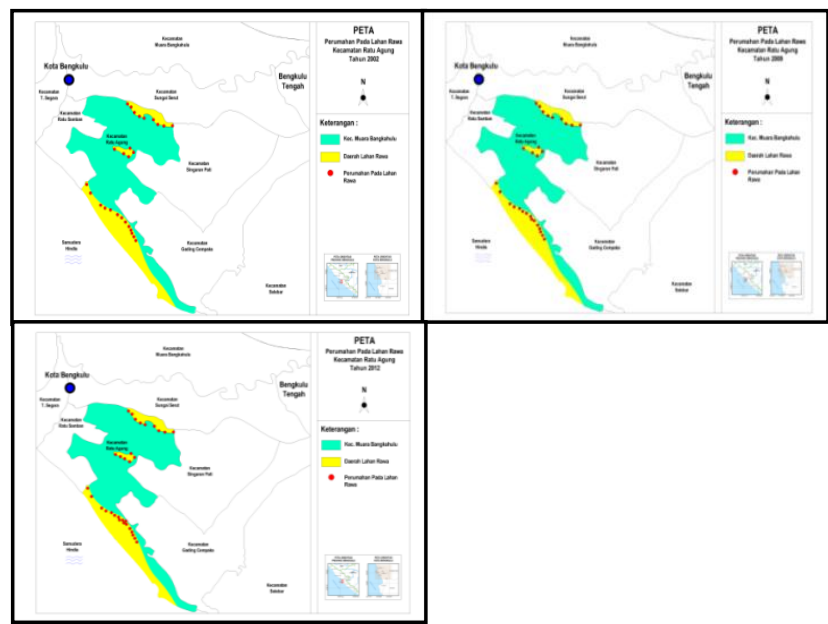

Figure 5 Total Houses in Wetlands in Ratu Agung District 2002, 2009 and 2012

\subsection{Soil Investigation Using Hand bore Instrument}

In this research, soil samples were taken using a hand bore at a depth ofimeter, then the soil samples taken were tested in the laboratory through a directs hear analysis to obtain the value of soil cohesion and soil friction angle. Before the directs hear test, the sample was first weighed and then the ring samples were measured to calculate the soil density.

The correlation among cohesion value (c), soil friction angle $(\phi)$ and soil $\operatorname{density}(\gamma)$ is the bigger cohesion value, the smaller soil friction angle and the more pliant the clay will be. The more pliant the clay means the less soil weight and affects to the less soil density.

After getting parameter of bearing capacity, the next step was calculating using equation (1) for ultimate bearing capacity and equation (6) for allowable bearing capacity. The calculating of bearing capacity on groundwater surface has to consider the rules explained in figure 1 . Value of ultimate bearing capacity $\left(q_{u l t}\right)$ and the allowable bearing capacity $\left(q_{a}\right)$ at any point in the research are shown as follows table 7 . 
Table 5 Cohesion Value $(c)$, Soil Friction Angle $(\phi)$, and The Average Soil Density $(\gamma)$

\begin{tabular}{|c|c|c|c|c|c|}
\hline No & Location & Name & $\begin{array}{c}c \\
\left(\mathrm{~kg} / \mathrm{cm}^{2}\right)\end{array}$ & $\begin{array}{c}\phi \\
\text { (degree) }\end{array}$ & $\begin{array}{c}\gamma \\
\left(\mathrm{kg} / \mathrm{cm}^{3}\right)\end{array}$ \\
\hline \multirow[t]{19}{*}{1} & Muara & Point 1 & 0.36461 & 6.90553 & 0.00181 \\
\hline & \multirow{14}{*}{$\begin{array}{l}\text { Bangkah } \\
\text { ulu } \\
\text { District }\end{array}$} & Point 2 & 0.14164 & $5 \cdot 36291$ & 0.00184 \\
\hline & & Point 3 & 0.10541 & 21.5670 & 0.00176 \\
\hline & & Point 4 & 0.32861 & 8.07666 & 0.00172 \\
\hline & & Point 5 & 0.49525 & 9.94500 & 0.00175 \\
\hline & & Point 6 & 0.34916 & 1.41514 & 0.00180 \\
\hline & & Point 7 & 0.63505 & 7.96286 & 0.00180 \\
\hline & & Point 8 & 0.38168 & 2.58479 & 0.00189 \\
\hline & & Point 9 & 0.37779 & 7.61402 & 0.00178 \\
\hline & & Point 10 & 0.24824 & 12.1331 & 0.00178 \\
\hline & & Point 11 & 0.39362 & 1.30897 & 0.00196 \\
\hline & & Point 12 & 1.36499 & 0.47893 & 0.00176 \\
\hline & & Point 13 & 1.08101 & 0.50015 & 0.00163 \\
\hline & & Point 14 & 0.66715 & 9.53587 & 0.00173 \\
\hline & & Point 15 & 1.60744 & 0.28308 & 0.00183 \\
\hline & \multicolumn{2}{|c|}{ Average } & 0.56988 & 6.37833 & 0.00179 \\
\hline & \multicolumn{2}{|c|}{ Deviation standard } & 0.44385 & $5 \cdot 76910$ & 0.00008 \\
\hline & \multicolumn{2}{|c|}{ Max } & 1.61403 & 21.5670 & 0.00196 \\
\hline & \multicolumn{2}{|l|}{ Min } & 0.10541 & 0.28308 & 0.00163 \\
\hline \multirow[t]{13}{*}{2} & Sungai & Point 1 & 0.33532 & $3 \cdot 56228$ & 0.00181 \\
\hline & Serut & Point 2 & 0.58303 & 5.64339 & 0.00184 \\
\hline & \multirow[t]{7}{*}{ District } & Point 3 & 0.49409 & 1.24538 & 0.00174 \\
\hline & & Point 4 & 0.13835 & 11.1794 & 0.00112 \\
\hline & & Point 5 & 0.75400 & 1.02971 & 0.00150 \\
\hline & & Point 6 & 0.10804 & 6.41601 & 0.00159 \\
\hline & & Point 7 & 0.27414 & 14.2828 & 0.00170 \\
\hline & & Point 8 & 0.62255 & 1.41514 & 0.00169 \\
\hline & & Point 9 & 0.02949 & $17 \cdot 3823$ & 0.00173 \\
\hline & \multicolumn{2}{|c|}{ Average } & 0.37100 & 6.90615 & 0.00163 \\
\hline & \multicolumn{2}{|c|}{ Deviation standard } & 0.25511 & 6.04311 & 0.00022 \\
\hline & \multicolumn{2}{|c|}{ Max } & 0.75400 & $17 \cdot 3823$ & 0.00184 \\
\hline & \multicolumn{2}{|c|}{ Min } & 0.02949 & 1.02971 & 0.00112 \\
\hline
\end{tabular}

Sources: Calculation Results, 2013

Table 7 Calculation results of the ultimate bearing capacity and allowable bearing capacity

\begin{tabular}{|c|c|c|c|c|}
\hline No. & Location & Name & $q_{\text {ult }}\left(\mathrm{kg} / \mathrm{cm}^{2}\right)$ & $\begin{array}{c}\boldsymbol{q}_{a} \\
\left(\mathrm{~kg} / \mathrm{cm}^{2}\right)\end{array}$ \\
\hline \multirow[t]{19}{*}{1.} & Muara & Point 1 & 1.92660 & 0.64220 \\
\hline & Bangkahulu & Point 2 & 0.80094 & 0.26698 \\
\hline & \multirow[t]{13}{*}{ District } & Point 3 & 1.49198 & 0.49733 \\
\hline & & Point 4 & 1.82488 & 0.60829 \\
\hline & & Point 5 & 2.84279 & 0.94760 \\
\hline & & Point 6 & 1.51644 & 0.50548 \\
\hline & & Point 7 & $3 \cdot 35442$ & 1.11814 \\
\hline & & Point $8^{*}$ & 1.93548 & 0.64516 \\
\hline & & Point 9 & 2.04172 & 0.68057 \\
\hline & & Point 10 & 1.71440 & 0.57147 \\
\hline & & Point 11 & 1.69839 & 0.56613 \\
\hline & & Point 12 & $5 \cdot 39779$ & 1.79926 \\
\hline & & Point 13 & 4.29300 & 1.43100 \\
\hline & & Point 14 & 3.70528 & 1.23509 \\
\hline & & Point 15 & 6.32313 & 2.10771 \\
\hline & \multirow{2}{*}{\multicolumn{2}{|c|}{$\begin{array}{c}\text { Average } \\
\text { Deviation standart }\end{array}$}} & 2.72448 & 0.90816 \\
\hline & & & 1.58601 & 0.52867 \\
\hline & \multicolumn{2}{|c|}{ Max } & 6.32313 & $\begin{array}{c}2.10771 \\
0.26698\end{array}$ \\
\hline & \multicolumn{2}{|l|}{ Min } & 0.80094 & \\
\hline
\end{tabular}

\begin{tabular}{|c|c|c|c|c|}
\hline No & Location & Name & $\begin{array}{c}q_{\text {ult }} \\
\left(\mathrm{kg} / \mathrm{cm}^{2}\right)\end{array}$ & $\underset{\left(\mathrm{kg} / \mathrm{cm}^{2}\right)}{q_{a}}$ \\
\hline \multirow[t]{13}{*}{2.} & Sungai & Point 1 & 1.57645 & 0.52548 \\
\hline & Serut & Point 2 & 2.83734 & 0.94578 \\
\hline & \multirow[t]{7}{*}{ District } & Point 3 & 2.07916 & 0.69305 \\
\hline & & Point $4^{*}$ & 0.85600 & 0.28533 \\
\hline & & Point $5^{*}$ & 3.06325 & 1.02108 \\
\hline & & Point $6^{* *}$ & 0.65759 & 0.21920 \\
\hline & & Point $7^{*}$ & 1.93682 & 0.64561 \\
\hline & & Point $8^{* *}$ & 2.60238 & 0.86746 \\
\hline & & Point $9^{* *}$ & 0.60862 & 0.20287 \\
\hline & \multicolumn{2}{|c|}{ Average } & 1.80196 & 0.60065 \\
\hline & \multicolumn{2}{|c|}{ Deviation standart } & 0.94060 & 0.31353 \\
\hline & \multicolumn{2}{|c|}{ Max } & 3.06325 & 1.02108 \\
\hline & \multicolumn{2}{|c|}{ Min } & 0.60682 & 0.20287 \\
\hline
\end{tabular}

Sources: Calculation Results, 2013

* $\quad=$ ground water level above the bottom of foundation

$* *=$ ground water lever below the bottom of foundation

Based on Table 7 , the allowable bearing capacity in the study site can be shown on the following map:

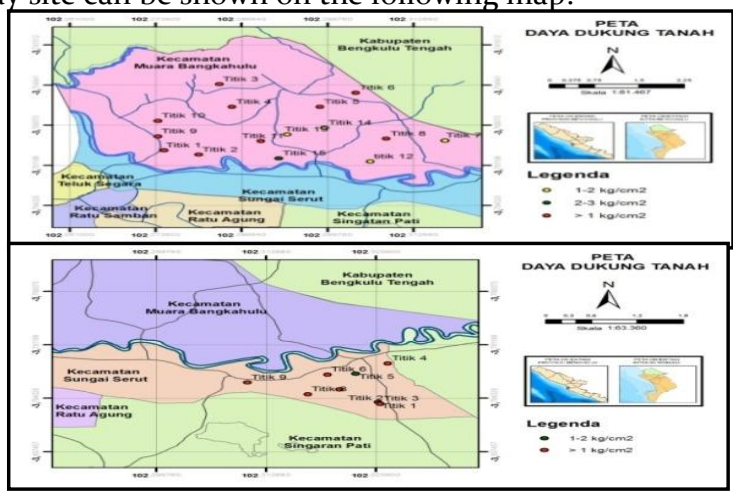

Figure 6 The Map of Allowable Bearing Capacity in Muara Bangkahulu District and Sungai Serut District

Based on Tablez, the correlation between the value of cohesion with soil type obtained at each point within the research site. The soil types can be seen in Table8, as follows;

Table 8 Soil type at each point research

\begin{tabular}{llcc}
\hline No. & Location & Name & Soil Type \\
\hline 1. & Muara & Point 1 & Very soft clay \\
& Bangkahulu & Point 2 & Very soft clay \\
District & Point 3 & Very soft clay \\
& Point 4 & Very soft clay \\
& Point 5 & soft clay \\
& Point 6 & Very soft clay \\
& Point 7 & soft clay \\
& Point $8^{*}$ & Very soft clay \\
& Point 9 & Very soft clay \\
& Point 10 & Very soft clay \\
& Point 11 & Very soft clay \\
& Point 12 & Stiff clay \\
& Point 13 & Stiff clay \\
& Point 14 & soft clay \\
& Point 15 & Stiff clay
\end{tabular}




\begin{tabular}{llcc} 
No. & Location & Name & Soil Type \\
\hline 2. & Sungai Serut & Point 1 & Very soft clay \\
& District & Point 2 & soft clay \\
& Point 3 & soft clay \\
& Point $4^{*}$ & Very soft clay \\
& Point $5^{*}$ & soft clay \\
& Point $6^{* *}$ & Very soft clay \\
& Point $7^{*}$ & Very soft clay \\
& Point $8^{* *}$ & soft clay \\
& Point $9^{* *}$ & Very soft clay \\
\hline
\end{tabular}

Source: calculation result, 2013

Based on the table above, the type of soil in the research site can be described by the following map:

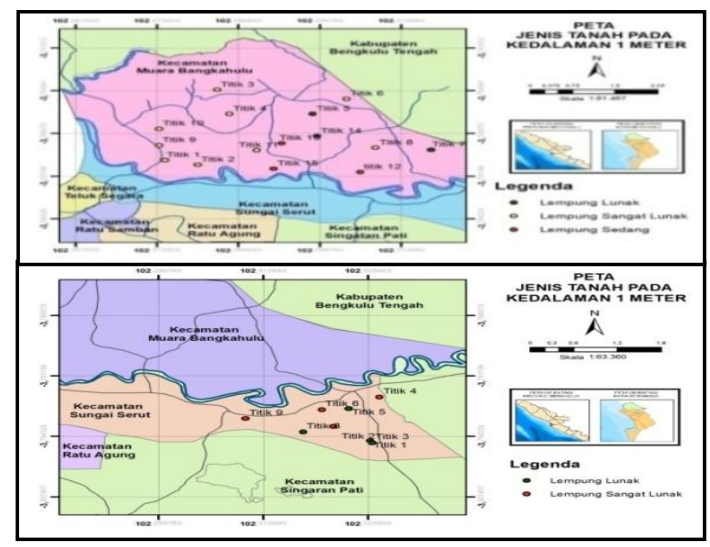

Figure 7 The map of Soil Types at Muara Bangkahulu District and Sungai Serut District

\subsection{Result of Soil Research using a Sondir}

The table below is the value of pressure/barriers conus $\left(q_{c}\right)$ atthe depth of 1 meter, used for the calculation of allowable bearing capacity:

Table 9The $q_{c}$ value at Ratu Agung District

\begin{tabular}{cccc}
\hline No. & Location & Name & $\boldsymbol{q}_{\mathbf{c}}\left(\mathbf{k g} / \mathrm{cm}^{2}\right)$ \\
\hline 1. & Ratu Agung & Point 1 & 75.77 \\
& District & Point 2 & 24.25 \\
& Point 3 & 32.33 \\
& Point 4 & 28.29 \\
& Point 5 & 56.58 \\
\hline
\end{tabular}

Source: Mutakdir, 2013

Based on the $q c$ values in Table 9, the calculations of allowable bearing capacity can be completed. The obtained value of allowable bearing capacity using sondir data can be seen in the following table.

Table 10 Value of Allowable Bearing Capacity $\left(q_{a}\right)$

\begin{tabular}{cccc}
\hline No. & Location & Name & $\boldsymbol{q}_{c}\left(\mathbf{k g} / \mathbf{c m}^{2}\right)$ \\
\hline 1 & & Point 1 & 2.52576 \\
2 & & Point 2 & 0.80824 \\
3 & Ratu Agung & Point 3 & 1.07766 \\
4 & District & Point 4 & 0.94295 \\
5 & & Point 5 & 1.88590 \\
6 & & Point 6 & 1.07766 \\
\hline
\end{tabular}

Source: calculation result, 2013
The allowable bearing capacity value at Ratu Agung District can be seen in the diagram below:

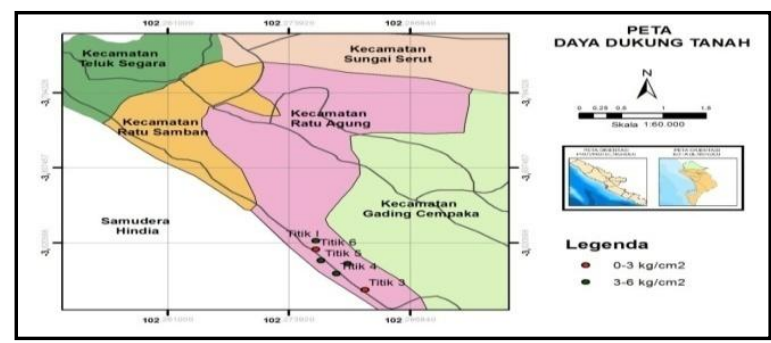

Figure 8The map of Allowable Bearing Capacity Value at Ratu Agung District

Determination of soil types from sondir test may use correlation graphs between the ratio of friction with Sondir limit resistance as demonstrated by Robertson and Campanella (1983) and is be shown in figure 2. Table 11 shows the types of soil at the depth of 1 meter for every point within the research site at Ratu Agung District:

Table 11 Soil Types within the Research Site at Ratu Agung District

\begin{tabular}{cccc}
\hline No. & Location & Name & Soil Type \\
\hline 1 & & Point 1 & sandy silt \\
2 & & Point 2 & sandy silt and silt \\
3 & Ratu Agung & Point 3 & sandy silt \\
4 & District & Point 4 & sandy silt \\
5 & & Point5 & sand \\
6 & & Point 6 & sandy silt \\
\hline
\end{tabular}

Source : Mutakdir (2013)

According to the research conducted in wetlands and swamps, the result has shown that in the targeted research site (Muara Bangkahulu, Sungai Serut and Ratu Agung District) all districts have a dominant bearing capacity of $<1$ $\mathrm{kg} / \mathrm{cm}^{2}$.

The values shown in figures 6,7 and 8 demonstrate areas with good bearing capacity and it is hoped that these become the guidelines for Bengkulu city government to decide planning zones for regional layout and associated structures, especially for non-engineered, social structures.

\section{CONCLUSIONS AND SUGGESTIONS}

\subsection{Conclusion}

1) Wetland is shrinking every year because of the increasing incursion from house building into wetland areas. The land which was wetland previously has been adapted by means of land filling, and turned into settlement areas.

2) The characteristics of soil which were identified are highly varied, there are three soil types; very soft clay, soft clay and stiff clay. Most of the soil types at the research points are very soft clay with a soil cohesion value of about $0.02949 \mathrm{~kg} / \mathrm{cm} 2-0.39362 \mathrm{~kg} / \mathrm{cm} 2$. While the other areas are differing kinds of soft clay with cohesion values of about $0.49409 \mathrm{~kg} / \mathrm{cm} 2-0.75400$ 
$\mathrm{kg} / \mathrm{cm} 2$ and stiff clay with values of about $1.0810 \mathrm{~kg} / \mathrm{cm} 2$ $-1.60744 \mathrm{~kg} / \mathrm{cm} 2$.

3) The value of allowable bearing capacity obtained from the identification results of the hand bore instrument is predominantly $<1 \mathrm{~kg} / \mathrm{cm} 2$ with a range of bearing capacities, in ranging from about $0.20287 \mathrm{~kg} / \mathrm{cm} 2$ $2.10771 \mathrm{~kg} / \mathrm{cm}^{2}$.

4) Characteristics of the soil identification results using a sondir instrument at Ratu Agung District were shown to be dominated by sandy silt however there are 2 research points which have a type of sandy soil and sandy silt and silt. While the value of pressure/conus barriers about $24.25 \mathrm{~kg} / \mathrm{cm} 2-75.77 \mathrm{~kg} / \mathrm{cm} 2$.

5) The values of allowable bearing capacity obtained from the identification tool sondir are in the range of 0.80824 $\mathrm{kg} / \mathrm{cm} 2-2.52576 \mathrm{~kg} / \mathrm{cm} 2$.

\subsection{Suggestion}

1) The analysis of soil investigation and soil structure improvement should be done before building houses.

2) The building of non engineered structures on wetlands and swamps should consider the low value of the bearing capacity of wetland area.

\section{References}

[1] Agus. 2002. Rekayasa Gempa Untuk Teknik Sipil. Padang; Biro Penerbit Institut Teknologi Padang.

[2] Ariani, A. 2013. Analisis Daya Dukung Tanah Untuk Lahan Pemukiman Di Kecamatan Muara Bangkahulu Kota Bengkulu. Thesis; Bengkulu.

[3] Das, B.M. 1994. Principles of Geotechnical Engineering. Surabaya; Erlangga.

[4] Dunn, I.S., Anderson, L.R., Kiefer, F.W. 1992. Fundamentals of Geotechnical Analysis. Semarang; IKIP Semarang Pers.

[5] Hardiyatmo, H.C. 2002. Mekanika Tanah 2. Yogyakarta; Gajah Mada University Pers.

[6] Hardoyo. S. R dkk, 2011, Strategis Adaptasi Masyarakat Dalam Menghadapi Bencana Banjir Pasang Air Laut di Kota Pekalongan, program Magister Perencanaan dan Pengelolaan Daerah Aliran Sungai dan Pesisir (MPPDAS). Fakultas Geografi. Book; Universitas Gadjah Mada.

[7] Muktadir, R. 2013. Evaluasi Potensi Likuifaksi Dengan Metode Determinasi Berdasarkan Data Cone Penetration Test (Studi Kasus Kelurahan Lempuing Kota Bengkulu). Thesis; Bengkulu.

[8] Reinhold, V.N. 1991. Soil Mechanic, Fouth Edition. Jakarta; Erlangga.

[9] Rifandi, M. 2013. Analisis Rumah 1 Lantai Pada Tanah Lunak di Kota Bengkulu Dengan Program Komputer (Analisis Struktur). Thesis; Bengkulu.

[10] Supribadi. 2002. Ilmu Bangunan Gedung. Armico 